\title{
The Political Economy of Reforms: \\ Empirical Evidence from Post-Communist Transition in the 1990s*
}

\author{
Byung-Yeon Kim
}

(University of Essex)

and

\section{Jukka Pirttilä}

(University of Cambridge and Bank of Finland)

This version: January 2003

\begin{abstract}
:
Using a novel data set from post-communist countries in the 1990s, this paper examines the linkages between political constraints, economic reforms and growth. Results from a dynamic panel analysis suggest that public support for reform is negatively associated with increases in income inequality and unemployment. In addition, both ex post and ex ante political constraints referring to the extent of public support affect progress in economic reforms, which in turn determines economic growth. These findings highlight that while economic reforms are needed to foster growth, they must be designed in such a way that they do not undermine political support for reform.
\end{abstract}

Key words: Political constraints, economic reform, transition, growth, dynamic panel models JEL classification Number: P26; O11; C33.

Word counts: 8385 including tables.

\footnotetext{
*: We are grateful to Pertti Haaparanta for his helpful comments and suggestions. An earlier version of this paper was presented at seminars at the Bank of Finland and the WIDER. We would like to thank seminar participants for their useful comments and suggestions.

Addresses for correspondence: B-Y Kim, Department of Economics, University of Essex, Wivenhoe Park, Colchester CO4 3SQ, U.K., email: bykim@essex.ac.uk, and Jukka Pirttilä, Clare Hall, Herschel Road, Cambridge, CB3 9AL U.K., email: JOP22@econ.cam.ac.uk.
} 
Genuine policy advice from economists often collides with political reality, leading to a failure of implementing first-best solutions. Economic debates usually involve what constitutes good economic policy, without necessarily taking political constraints into account. During recent years, however, there has been the revival of interest in the more practical, but yet equally inspiring side of the coin, i.e. the political economy of economic policy. Two much debated books by Drazen (2000) and Persson and Tabellini (2000) reflect a growing emphasis on the political economy ${ }^{1}$. One of the research areas these studies are concerned with is the political economy of reforms. Specific issues this area deals with include: why are reforms delayed?; what determines support for reforms?; how can reforms be better implemented?; what is the optimal speed and sequencing of reforms?

Arguably, one of the most far-reaching events in the economic history of the $20^{\text {th }}$ century was the collapse of socialist economies in Eastern Europe and former Soviet Union, and their subsequent transition toward market economies. The economic consequences of the transition process have been often severely painful. After the start of the reforms, all countries have experienced a major fall in output. A majority of the transition countries have faced a sharp increase in income inequality and unemployment. For example, in Russia, output declined by about 40\% from 1992 to 1997, unemployment rose from $4.8 \%$ in 1992 to $10.9 \%$ in 1997 , and income inequality expressed in Gini coefficient soared from 26.9 to 48.3 . Most of the countries started to grow only towards the end of the 1990s. Even now, the sustainability of long-waited economic boom is still questionable for Russia.

One unique feature in transitional countries in former Soviet republics and Eastern Europe is that the transition process has involved democratisation as well as marketisation. Almost all countries attempted political liberalisation by establishing democracy and civic freedom at the early 
stage of the transition. From the very early on, therefore, all wide-ranging economic reforms must have been passing through the political process. As a result of worsening economic well-being at least in the early years of transition, there might have been an immediate feedback from economic experience to politics in order to block the implementation of radical market reforms, either by exerting political pressure on a reform-oriented government or by reinstating a communist or socialist party through an election.

Policy choices varied markedly across these transition economies. Countries were often classified as full (big-bang) reformers or as partial reformers. Policies have been especially distinct with respect to austereness of stabilisation, speed and forms of privatisation, and tolerance towards rent seeking. This indicates that policy decisions by politicians have not been dictated simply by economic circumstances: politics or more specifically mass support has been important for policy making.

The combination of the sudden start of transition, the rapid establishment of democratic institutions affecting the nature and speed of reforms, and variances in policy choices across the transition countries provides a unique opportunity, arguably one close to laboratory circumstances, to investigate the interaction between political process and economic reforms. In other words, the transition experience offers an unrivalled opportunity to test the political economy theories of reforms. In contrast, in many of the Latin American and east-Asian countries, whose experience has been widely used in earlier political economy literature, have a long history of path-dependence of reforms. Thus, it might be difficult to distinguish the contemporaneous political feedback to reforms from the effect of path-dependency on reforms. Moreover, in most east-Asian countries, economic reforms preceded political transformation, suggesting a feedback from economic experience to politics has been slow and weak.

The importance of studying the political economy of reforms in transition countries has been reflected in a large volume of both theoretical and empirical research. Among these, Blanchard

\footnotetext{
${ }^{1}$ An earlier synthesis is provided by Rodrik (1996).
} 
(1997) highlights the interactions between macroeconomic variables, such as unemployment and budget deficits, and the optimal speed of transition reforms. Roland (2000) focuses on many political economy aspects of reform, particularly on how political constraints determine a reform path. The growing body of empirical work (see eg Berg et al 1999; Havrylyshyn et al., 1998; Campos and Coricelli, 2001), suggests that economic reforms (liberalisation and restructuring), prudent macroeconomic policies (low inflation and small budget deficits) and beneficial initial conditions (relatively small distortions before transition, the experience of pre-transition reforms and beneficial geographical location among other things) are the crucial determinants of growth during the transition. However, existing macro-level empirical studies tend to overlook the interactions between economic reforms, political constraints and growth. ${ }^{2}$ As a result, many of the recent important theories have not been tested yet.

In this paper, we attempt to fill the gap between the key theories of the political economy of reforms and empirical research on growth in transition countries. We use a novel data set that makes it possible to build a dynamic panel econometric model to test the relationships between public support for reforms, progress in reforms, and economic growth. We first examine what determines support for economic reform among citizens. Our key focus is on how economic outcome from earlier reforms and material well-being of individuals, such as growth, inflation, unemployment, and income inequality, affect support for future reforms. Public support for reform is likely to act as either ex ante political constraints (that may block reforms before their being launched) or ex post constraints (backslash and policy reversal). Second, we test the extent to which these political constraints have exerted influence on the nature of economic policies. This can be viewed as a way to study empirically the validity of political economy models of reforms in the transition context. The chosen reform may also be related to past macroeconomic outcomes, opening up a way to test the endogeneity of policies to economic variables, as highlighted in the literature on the optimal speed of reforms such as Blanchard (1997). Third, we examine how reforms affect growth, employ-

\footnotetext{
${ }^{2}$ There are studies (Fidrmuc 2000, Jackson et al (2001) and Warner 2001, among others) building on evidence from
} 
ing dynamic panel models that address some of the issues overlooked by the existing literature on growth in transition countries. These include treating the three equations of the determinants of growth, support for reforms and progress in reforms as a system, and taking account of the dynamic nature of transitions using the GMM estimator of Arellano and Bond (1991).

Our results suggest that support for reform is dependent on the past macroeconomic performance, and especially on developments that directly concern the well-being of people, such as unemployment, inflation and income inequality. The support for reform, in turn, is a crucial determinant of a reform path. This finding implies that political constraints have played a key role in shaping economic policies in transition countries: transition reforms are not an exogenous process but crucially dependent on the political economy considerations. In addition, we find that accumulated reform progress affects economic growth positively, which dominates the negative short-run impact of reform on growth.

The paper proceeds as follows. Section 2 reviews theoretical research on the political economy of transition and earlier empirical work on growth in transition countries. Section 3 presents the data and our empirical approach. In Sections 4, we present our main results, which are checked for their robustness in Section 5. We summarise our main findings in Section 6.

\section{Public support, reform progress and economic growth in transition countries: litera- ture survey}

\section{Political constraint of economic reform and determinants of public support}

In any democratic country, a decision to launch or continue major reforms requires sufficient public support. Emphasising the importance of political constraints in adopting and carrying out a reform programme, Drazen $(2000$, p. 624) claims that the political problem in transition is that for a program of reform and transition to succeed, it must have the necessary political support at 
crucial decision stages. Given high uncertainty regarding the success of a reform and a newly created democracy, one can argue that political constraints play an extremely important role in policy making in transition countries.

Several studies analysed the role of political constraints on economic reforms. Rodrik (1994) argues that the consequences of reform often involve the redistribution of income among different groups. Thus economic reforms are not or only gradually implemented unless the efficiency gain from reforms are substantial and income is redistributed in a way that minimises the opposition. The probability of voting against reform may increase because of individual uncertainty. For example, Fernandez and Rodrik (1991) suggest that some of the eventual winners would vote against the adoption of an efficiency-gaining reform package because the losers are not identified $e x$ ante.

Ex post political constraints are also analysed in Wyplosz (1993) and Dewatripont and Roland (1995). In more detail, Wyplosz (1993) maintains that the continuation of a reform requires a more stringent condition compared to a condition that enables the reform to start. This model assumes the unanimity rule, under which the government concerns with income distribution between the losers and winners even though the losers are minority. Dewatripont and Roland (1995) provide a model that contains both aggregate and individual uncertainties. Due to aggregate uncertainties, a partial reform (defined as implementing part of reforms) might be beneficial for the society, because of the existence of an early reversal option. Furthermore, sequencing is important: a partial reform that increases the welfare of a median voter will lead to the continuation of another reform if the aggregate outcome is positive. This suggests that starting with a reform that increases the welfare of a majority runs a smaller risk of reversal.

If political constraints are important for the start and continuation of a reform, the government needs to design mechanisms to compensate the losers. Otherwise, a status-quo bias or a reform reversal is likely. During transition, unemployment is likely to increase. In order to reduce the blocking of a reform by the unemployed, the government needs to provide unemployment benefits. 
In these conditions, Dewatripont and Roland (1992) point out that a slower, feasible speed of transition may be preferable because the pressure on fiscal sector can be lessened. This has an implication for the optimal speed of transition. For example, Aghion and Blanchard (1994) highlight the role of fiscal balance affected by unemployment benefits in the decision of the speed of reform. If the government adopts a big-bang reform that leads to shedding too many jobs, the fiscal burden becomes so large, which will make both the restructured state sector and the private sector unprofitable. This suggests that there is an a slower, optimal speed of transition that allows not also for both the state and private sectors to operate at positive profitability but also for the government to maintain sufficient public support for the continuation of a reform.

There are only a few studies that provide empirical evidence on whether political constraints are indeed important in the nature, adoption, and reversal of reforms. Lora (1998) constructs reform measures for 19 Latin American and Caribbean countries for the period of 1985-1995, and regresses several political and economic variables on the adoption of reforms. The results suggest that the adoption of reforms is positively correlated economic crises such as negative GDP growth and past inflation.

Fidrmuc (2000) investigates the political support for reforms in four transition countries by looking at the relationship between votes received by different parties (reform support) and economic factors. He finds that the support for reformist parties is negatively correlated with unemployment but positively associated with the size of the private sector. These findings indicate that the distributional aspect of reform is one of the significant factors to influence the support for reform. Using data on four Polish elections, Jackson et al., (2001) support the hypothesis that economic factors are important in explaining political support for reforms. According to them, support for pro-reform parties significantly depends upon job creation in new firms that replaces job losses in former state-owned enterprises. Warner (2001) uses data of Russian regions to looks at the effect of reform progress on support for pro-reform parties in December 1995 parliament elections, and finds that reforms created a positive feedback to politics rather than backlash against reforms. 


\section{Reform progress and economic growth}

A large number of studies investigate the relationship between economic reform and economic growth. ${ }^{3}$ Early studies (De Melo et al., 1996; Fischer et al., 1996) find that an index of reform progress, compiled by the World Bank, is positively associated with economic growth. However, Krueger and Ciolko (1998) criticise such studies by arguing that the measure of reform is significantly correlated with the initial condition of reforms such as export share and GNP per capita before the start of the transition. They find that initial conditions play a larger role in output performance than reform-related variables that exclude their indirect effects on growth through initial conditions. In contrast, Havrylyshyn et al., (1998) suggest that even after controlling initial conditions, a variable relative to the economic reform index is significant. They also show that the shortterm effect of reform on growth may be negative but its long-term effect is sufficiently positive in a way that it dominates the short-term loss. Brunetti et al., (1997) emphasise the importance of institutions in economic performance: they find that variables such as rule of law and corruption significantly affect economic growth in transition countries. Yet, Havrylyshyn and van Rooden (2000) claim that the impact of institutional development on economic growth is statistically significant but not overwhelming.

However, there are important methodological drawbacks in existing empirical studies. First, there was an only limited effort to capture the dynamic nature of economic growth. Economic growth is a dynamic phenomenon: early positive growth may provide a momentum for further growth in later years, by increasing agents' confidence in the economy, by providing the government with more rooms for policy manoeuvre, and by reducing political constraints using larger resources available from positive economic growth. Second, although many variables used as dependent or independent variables are potentially correlated, existing studies tend to pay insufficient attention to the issues of endogeneity and multi-collinearity. For example, unobserved shock may 
cause the correlation between error-terms and economic growth. In addition, the speed of privatisation may be correlated with fiscal balance of the economy, while exchange rate regime can be correlated with inflation rates.

Berg et al., (1999) present a partial effort to take above criticisms into account. They include previous economic growth as regressors for the estimation of current economic growth and use IMF targets for macroeconomic variables as a proxy of an index of reform progress in order to mitigate the endogeneity problem of the measure of reform progress. They find that although no single policy variable is robust enough to exclusion tests, reform-related measures are often significant. Yet, one can argue that instrumenting only the reform index and estimating the model using a fixed-effects estimator is a partial solution. Furthermore, by including lagged growth variables as regressors, it creates another so called Nickell's bias.

Let alone methodological problems, literature on economic growth overlooks one potentially important dimension: how reform progress is determined. Theoretical literature, as we reviewed earlier, suggests that political constraints should affect the nature and speed of reform. By treating reform progress exogenous, earlier literature on economic growth disregards the possibility of feedback from economic performance onto reform progress through public support for the reform.

\section{Empirical framework and econometric methods}

\section{Reform support}

We assume that support for a market-oriented reform is a function of variables that can be classified into three groups: income distribution, macroeconomic performance, and time-invariant fixed effects. We include income inequality and unemployment as income distribution-related variables, in order to use them as a proxy of ex post political constraints. The importance of the two

\footnotetext{
${ }^{3}$ Harvylyshyn et al., (1998) and Campos and Coricelli (2001) provide a survey of empirical studies on economic
} 
variables in explaining support for reform was extensively discussed in several studies (Dewatripont and Roland, 1992; Wyplosz, 1993; Aghion and Blanchard, 1994; Fidrmuc, 2000). Inflation and economic growth rates, which represent macroeconomic performance, are likely but not exclusively to affect the whole population in a way that it affects the mean of public support. The variables relating to the third group include all fixed effects including initial conditions and institutions. It is likely that ideological and other country-specific unobserved characteristics affect support for reform, but we believe that these are captured to a great extent by country-specific fixed effects. Therefore, we estimate the following equation:

$$
\operatorname{reform}_{i t}=\alpha_{i}+\beta \text { reform }_{i t-1}+\sum_{j=0}^{j=1} r_{i j} \text { unemp }_{i t-j}+\sum_{j=0}^{j=1} \delta_{i j} \text { gini }_{i t-j}+\sum_{j=0}^{j=1} \phi_{i j} \text { grow }_{i t-j}+\sum_{j=0}^{j=1} \lambda_{i j} l \inf l a_{i t-j}+\varepsilon_{i t}
$$

where subscripts $i$ and $t$ denote country and year, respectively, reform ${ }_{i t}$ is support for reform toward a market economy, unemp $_{i t}$ denotes unemployment rates, gini $i_{i t}$ is gini coefficients, grow $_{i t}$ is growth rates of GDP, and linfla $i_{i t}$ denotes log of inflation rates in country.

The dependent variable, reform, is based on information from the Central and Eastern Eurobarometer (CEEB) surveys, which were commissioned by the European Union and had been conducted from 1990 to $1997 .^{4}$ The sources for other variables are official statistics from the IMF and the EBRD. The countries we are concerned with are Armenia, Belarus, Bulgaria, Czech Republic, Estonia, Hungary, Latvia, Lithuania, Poland, Romania, Russia, Slovakia, Slovenia, and Ukraine.

The CEEB surveys are annual surveys, which have been monitoring economic and political changes, and attitudes towards Europe and the European Union. The regular CEEB sample size is about 1,000 respondents per country. The dependent variable, reform, is measured by subtracting

\footnotetext{
growth in transition economies.

${ }^{4}$ The samples are drawn among the citizens of the respective country, of 15 years and over. Respondents are interviewed face-to-face, in their private residences. A multi-stage random probability sample design has been applied for all countries (except Hungary which adopted a quota sampling technique for survey 2). The details of the surveys and questionnaire can be obtained from http://www.social-science-gesis.de/en/data_service/eurobarometer/ceeb/.
} 
the share of respondents who answered "wrong" from that of those who replied "right" to the following question:

Do you personally feel that the creation of a free market economy, that is, one largely free from the state control, is right or wrong for (our country's) future?

Note that we specify a dynamic model by including the lagged dependent variable. Following a general to specific approach, we test the dynamic model including all the lagged variables and then present a parsimonious model after deleting insignificant variables. We first estimate Equation (1) using a fixed effects model, which eliminates country-specific time invariant variables. Next we use GMM model to take account of measurement errors in variables and possible endogeneity biases.

We test ex ante political constraints in contrast with ex post political constraints. Equation (1) assumes that public support for a market reform is affected by past and current economic variables that might determine the winning or loss of an individual. Yet, one can claim that future probability of winning or loss is also important. These ex ante political constraints are tested using the data from the CEEB surveys. The surveys ask a question:

Over the next 12 months, do you expect that the financial situation of your household will (get a lot better, get a little better, stay the same, get a little worse, and get a lot worse)?

The respondent was asked to choose one of the five options. We measure the variable relative perceived future winning/loss by: first, summing the share of respondents who answered their situation will get a lot better and that of those who said a little better, second, summing the share of respondents who answered their situation will get a little worse and that of those who said a lot worse, and third, we divide the former share by the latter share.

In a similar way, we can directly use the data on ones' perceived financial situations during past twelve months, as another proxy of ex post constraint. The question is:

Compared to 12 months ago, do you think that the financial situation of your household has (got a lot better, got a little better, stayed the same, got a little worse, and got a lot worse)? 
If we incorporate these two variables in equation (1), the equation changes to:

$$
\text { reform }_{i t}=\alpha_{i}+\text { Breform }_{i t-1}+\sum_{j=0}^{j=1} r_{i j} \text { unemp }_{i t-j}+\sum_{j=0}^{j=1} \delta_{i j} \text { gini }_{i t-j}+\sum_{j=0}^{j=1} \phi_{i j} \text { grow }_{i t-j}+\sum_{j=0}^{j=1} \lambda_{i j} \operatorname{linf}_{\text {inf }} a_{i t-j}+\text { cfutloss }_{i t}+\text { yretloss }_{i t}+\varepsilon_{i t}
$$

where, futloss $i$ is the perceived winning/loss in coming twelve months, measured as explained above, and retloss $i t$ is the perceived winning/loss in the past twelve months.

We estimate the equation (1)' to check robustness of our first step baseline equation (1). In particular, the significance of retloss together with the other income-distribution related variables indicate that retloss has independent information that is not captured by gini or unemp.

\section{Progress in reform}

The government is assumed to take into account two factors when it designs, adopts and implements a reform: support from the mass public for a market-oriented reform and macroeconomic performance. The former is straightforward to interpret: without a sufficient support from the public, it would be difficult for the government to carry out reform policies.

Macroeconomic performance can also affect reform progress directly because it might ease resource constraints faced by the government. For example, too high unemployment rates may affect reform progress not only indirectly through public's support for a reform but also directly through needed spending on social safety net. Government fiscal balance can also play a role in reform progress. For a government that suffers from a high fiscal deficit would it be difficult to pursue policy leading to increases in government expenditure: for example, policy aiming at rapid restructuring may result in increases in government expenditure.

Thus, we model progress in reform as follows:

$$
l i_{i t}=\alpha_{i}^{\prime}+\beta^{\prime} l i_{i t-1}+\sum_{j=0}^{j=1} \kappa_{i j} \text { reform }_{i t-j}+\sum_{j=0}^{j=1} r_{i j}^{\prime} \text { unemp }_{i t-j}+\sum_{j=0}^{j=1} \delta_{i j}^{\prime} \text { gbal }_{i t-j}+\sum_{j=0}^{j=1} \phi_{i j}{ }^{\prime} \text { grow }_{i t-j}+\sum_{j=0}^{j=1} \lambda_{i j}^{\prime} l \inf l a_{i t-j}+\varepsilon_{i t}^{\prime}
$$


where, as the same in equation (1), $i$ and $t$ denote a country and year, respectively. $l i$ is the measure of reform progress, and gbal denotes the share of government budget balance in proportion to GDP.

For the dependent variable, the measure of reform progress, we use a structural reform index that represents the level of structural reforms achieved in each year. The index was compiled by the World Bank and has been used in several papers as a proxy of a reform progress (De Melo, et al., 1996; Fischer et al., 1998; Berg, et al., 1999). ${ }^{5}$ In order to take endogeneity of reform progress into account, we employ a two-step approach to estimate equation (2): first, we estimate equation (1); second, we replacing support for reform in the current period ( reform $\left._{i t}\right)$ with predicted one from equation (1). As in the estimation of equation (1), we use both fixed effects model and GMM to estimate equation (2).

\section{Economic growth}

Existing work on the determinants of economic growth in transition countries suggests there are four groups of variables that determine economic growth: progress in structural reform; macroeconomic policies; initial conditions; institutions. We follow their approach by including the key set of variables from these studies, namely, by incorporating determinants relating to reform progress and macroeconomic policies, but by treating variables relating to initial conditions and institutions as country-specific fixed effects.

However, our analysis differs from most of the earlier growth literature in the transition context by using the predicted index of reform progress (from step 2 regressions) instead of assuming that progress in reforms is completely exogenous. In addition, we use a dynamic specification using the Arellano-Bond (1991) GMM estimator for dynamic panels.

Most of the earlier studies emphasise that reforms may undermine growth in short term, but their beneficial long-term effect dominates, and therefore the overall relation between reforms and growth is positive. A short-cut way to capture this in a short panel such as ours is to include 
both contemporaneous reform index and lagged cumulative reform index as right-hand side variables. The prediction is then that contemporaneous reform may have a negative sign, whereas lagged cumulative reform should clearly have a positive impact on growth.

Thus, we estimate the following model:

$\operatorname{grow}_{i t}=\alpha^{\prime \prime}+\beta^{\prime \prime} \operatorname{grow}_{i t-1}+\kappa^{\prime \prime} l_{i t}+\gamma^{\prime \prime} \operatorname{cli}_{i t-1}+\sum_{j=0}^{j=1} \delta^{\prime \prime}{ }_{i j} \operatorname{gbal}_{i t-j}+\sum_{j=0}^{j=1} \phi_{i j}{ }^{\prime} \operatorname{capf}_{i t-j}+\sum_{j=0}^{j=1} \lambda^{\prime \prime}{ }_{i j} l \inf l a_{i t-j}+\operatorname{exch}_{i t}+\varepsilon^{\prime \prime}{ }_{i t}$

where, subscripts $i$ and $t$ denote a country and year, respectively. cli is accumulated progress in reform, measured by the sum of reform index, exch is a dummy that refers to whether a country adopts fixed exchange rate regime $(=1)$ or not $(=0)$, and capf denotes index of fixed capital formation. Although capital formation is not used in other studies on growth determinants in transition countries, literature on economic growth in non-transition countries frequently uses it as a regressor. $^{6}$

\section{Econometric results}

\section{What determines support for reform?}

In the first step of our empirical analysis, we examine the determinants of support of reforms (equation (1) above). These results are reported in Table 1. The basic results are obtained from models 1 (general) and 2 (parsimonious) ${ }^{7}$ that are based on a fixed effects estimator.

The results (especially from model 2) suggest that both increase in lagged unemployment and lagged inflation reduce support for reforms. This confirms that there is a feedback from actual

\footnotetext{
${ }^{5}$ This index is a weighted average of three indices: price liberalisation and competition, trade and foreign exchange regime, and privatisation and banking reform. For a detailed discussion on this measure, see de Melo et al., (1996).

${ }^{6}$ Data on economic growth, inflation rates, unemployment rates, exchange rate regime, fixed capital investment, government budget balance are from EBRD Transition Reports (various issues) and the World Bank data base. The source of gini coefficient is the United Nations University - World Institute for Development Economics Research (the data can be downloaded from http://www.wider.unu.edu/).

${ }^{7}$ As elsewhere in the paper, all the parsimonious models are obtained by dropping insignificant variables one by one from the general model.
} 
economic performance to public opinion on the reforms. In addition, increasing economic inequality (measured by Gini-coefficients) reduces the support for reforms. One explanation for the role of inflation is linked to wage and pension rigidities, implying that nominal price increases also reduce real income. Inflation may also have adverse distributional implications and may therefore be another proxy of inequality. It is also of interest to note that growth rates (on which most of the economic policy focuses) do not affect people's opinion about the benefits of reform.

In addition to the fixed effect regressions, we use GMM estimation to control for possible measurement errors in support for reforms. Lagged dependent variables turned out to be insignificant and therefore the results are based on static GMM estimation. Results from GMM regressions (models 3 and 4) confirm the overall picture depicted above. The tests reported do not reveal any problems in the specifications. Unemployment and Gini-coefficients are still clearly significant, whereas inflation is somewhat less significant.

What is the interaction between support for reforms, macroeconomic performance and chosen economic reforms?

Step 2 regressions examine how chosen economic reforms (measured by the World Bank aggregate liberalisation index, $l i$ ) depend on support for reforms and past macroeconomic performance. This analysis corresponds to equation (2) in section 3. Two linkages are of key interest: political economy factors ${ }^{8}$ and optimal speed of transition considerations.

These linkages are tested using a host of econometric specifications. Models 1 and 2 are based on two-step least squares (2SLS) estimation, where support for reform is first predicted from step 1 regression and then used as a determinant of chosen reform. ${ }^{9}$ The third model is similar to model 2, but standard errors are bootstrapped to check if inference remains the same as in the standard 2SLS with predicted reform. In models 1-3, contemporaneous macro-variables are dropped from the model to ensure that results do not suffer from endogeneity bias. A possible time lag be- 
tween the implementation of economic policy and changes in economic performance can also motivate this choice. Finally, GMM is used to allow for the inclusion of contemporaneous variables. Dynamic specification was first used (Arellano-Bond one-step estimation with robust standard errors), but as the lagged dependent variable turned out to be insignificant, the reported results are based on static GMM. Specification tests do not detect problems in the GMM models.

Results are shown in table 2. The main finding is that the predicted support for reform is significant for explaining progress in reforms. In other words, the probability of carrying our reform continuously is positively associated with public support for reforms. ${ }^{10}$ Likewise, if unsuccessful outcomes of earlier reforms undermine political support for reforms, future reforms would slow down. This provides empirical evidence that political constraints are an important consideration when politicians decide on the nature and speed of economic reforms. While intuitively clear, the finding is important in that it provides empirical evidence for the political economy models of transition.

Another interesting finding is related to the role of unemployment. High unemployment significantly reduces the pace of chosen reforms. This may be interpreted in the spirit of the Aghion-Blanchard (1994) transition model, where the optimal speed of transition is slower because of the effect of unemployment on a fiscal balance. ${ }^{11}$

Finally, results from the GMM estimation (models 4 and 5) complement the picture given above, although these results must be interpreted with caution because of the small sample size. Support for reform is still significant, whereas unemployment is not. It can be explained that the some of the effects of unemployment are channelled through the inclusion of contemporaneous fiscal balance. Higher unemployment is reflected in a worse fiscal position, and therefore there should

\footnotetext{
${ }^{8}$ At this stage, the analysis is related to ex post political constraints. Ex ante constraints are analysed in section 5.

${ }^{9}$ Model 2 is similar to 1 with the exception that lagged fiscal balance (gbal1) and lagged reform are dropped.

${ }^{10}$ reform variable is significant in all other specifications except 1 (lagged reform and gball may cause this) and 5 (which is the general specification of GMM). Reform variable is again significant in the final parsimonious GMM model, 6 .

${ }^{11}$ Although in their model the relationship between unemployment and optimal speed of reform is non-linear in a sense that small levels of unemployment are useful for reforms. Therefore a more correct test for this theory would use a nonlinear empirical specification as well.
} 
be a positive correlation between fiscal balance and reform progress. If a budget balance becomes more positive, beneficial reforms that are constrained by fiscal considerations can be implemented with a faster pace. ${ }^{12}$

\section{Explaining growth}

The final step is to examine how progress in reforms and other factors explain economic growth (corresponding to equation (3) in Section 3). Results reported in Table 3 reveal that lagged growth is clearly significant. The results also confirm the discussion above that in the short term, predicted reform has a negative sign, but lagged cumulative reform is a quantitatively larger positive factor and also statistically more significant. In model 1 (without exchange rate), high inflation undermines growth, whereas inflation is not precisely determined, if exchange rate regime is included (model 2). This suggests that fixed exchange rates have successfully curbed inflation in transition countries during the years this study considers. In addition, our analysis confirms earlier findings on the positive impact of prudent fiscal policy on growth. Turning on the role of investment, it is somewhat surprising that the contemporaneous capital formation has a positive sign whereas its lagged impact is negative.

\section{Economic significance}

First, we divided the countries into four groups in terms of their order in Gini coefficient and unemployment rates: the lowest, low, high and highest. The number of countries belonging to the lowest, low, high and highest was three, four, four and five, respectively. In order to understand the magnitude involved in our key results, suppose that a country was able to reduce Gini coefficients and unemployment rates by 6.6 and $3.4 \%$, respectively. These changes are equivalent to those from the mean of low Gini coefficient to the mean of the lowest Gini coefficient group, and from the mean of low unemployment rates to the mean of lowest unemployment groups, respectively.

\footnotetext{
${ }^{12}$ Dewatripont and Roland (1992) build a model where there is a trade-off between budget balance and chosen reforms.
} 
Since the coefficient on Gini and lagged Gini in the regression of support for reform is -0.9 and 0.97 as shown table 1 , column 4 , respectively, the aggregate impact of changes in Gini on support for reform is 12.4. This will lead to an increase in reform progress by 0.052 , because the coefficient on support for reform for the estimation of progress in reform is 0.0042 as shown in table 2, column 2. In the estimation of economic growth, two independent variables are constructed based on progress in reform. One is progress in reform itself in a corresponding year and another is accumulated progress in reform. Respective coefficients on accumulated reform and progress reform, which are 9.0 and -0.85 as depicted in table 3, column 2, suggest that an increase in Gini by 6.6 induces a rise in growth rate by $0.43 \%$. In the same way, a decrease in lagged unemployment by $3.4 \%$ results in a rise in a growth rate by $0.28 \%$. In other words, such reductions in income inequality and unemployment rates would increase economic growth rates by around $0.7 \%$ per annum. Since the difference in the mean of annual growth rates between fast growers and fastest growers is $3.2 \%$, the combined impact of Gini and unemployment accounts for $22 \%$ of differences in annual growth rates between the two groups. If we assume a more extreme case in which the mean of the highest Gini coefficients groups changes to the lowest and, at the same time, the mean of the highest unemployment rates changes to the lowest, it will increase annual growth rates by $1.9 \%$.

To be more illustrative, suppose that Russia reduced income inequality to the level of Poland, namely from 40.4 to 27.4 . This will lead to an increase in growth rate by $0.85 \%$. In a similar way, assume that Hungary was able to decrease the mean of unemployment rates from 1990 to 1997 to that of the Czech Republic in the same period, that is, from $9.4 \%$ to $3.2 \%$. This will induce an increase in annual growth rates by $0.51 \%$ ceteris paribus, which accounts for about $50 \%$ of the difference in the mean of growth rates between the two countries. These seem considerable. 


\section{Robustness analysis}

\section{The role of ex ante and ex post political constraints}

First, we focus on robustness analysis of equation (1), by estimating its variant (1)', reported in section 3. Equation (1)' includes both retloss (retrospective loss) and futloss (future loss) as additional explanatory variables. Then, ex post political constraints are captured either by earlier actual macroeconomic performance such as unemp and gini, or reported perceived loss (retloss). Yet, the key addition is the inclusion of perceived futloss, which can be interpreted as an ex ante political constraint (perceived future worsening in economic position reduces reform support and thus reform progress).

The findings reported in models 1 and 2 in Table 4 reveal that as earlier, increasing economic inequality and unemployment reduce support for reform. From the new variables, retloss in not significant, implying that ex post political constraints are captured by gini and unemp to a significant extent. An interesting result is that futloss is positively correlated with support for reform: support for reforms depends both on earlier outcome of the reforms and the perceived future losses. ${ }^{13}$ In other words, support for reform, which depends both on ex ante and ex post political constraints, is needed for carrying out actual reforms. ${ }^{14}$ Given the significance of futloss in determining support for reform, the combined impact of ex ante and ex post political constraints on economic growth increases significantly. Based on the assumption of changes from the mean of low Gini coefficient to the mean of the lowest Gini coefficient group and from the mean of low futloss to the mean of lowest futloss groups, a rise in public support for reform either by decreasing Gini and unemployment, or by increasing the share of people who view their financial situations more positively out of total population, results in a faster economic growth by $0.7 \%$ per annum. If we add this to the impact of unemployment on economic growth through support for reform, based on the

\footnotetext{
${ }^{13} \mathrm{We}$ also found that predicted reform that is calculated with the inclusion of futloss is significant in step 2 regression.

${ }^{14}$ These results are not reported here but can be obtained from the authors upon request.
} 
assumption of the change from the mean of low unemployment rates to the lowest unemployment rates group, the total effect of political constraints on economic growth is $0.84 \%$ per annum.

\section{Different reform indicators}

Let us now turn on some measurement issues in capturing actual reforms (in step 2 regressions). The measure used above, $l i$, is an aggregate of the World Bank liberalisation indices, lii (internal or price liberalisation), lie (external liberalisation) and lip (private sector entry, capturing e.g. privatisation and corporate governance). One can argue that support for reform may vary depending on the aspect of reform. To explore this, we used all the three indices separately as dependent variable in step 2 regressions. It turned out that support for reform is not significant in explaining internal and external liberalisation. This is understandable as most countries launched these reforms in the early stage of transition, and thus there is not much scope for (ex post) political constraints to affect these choices.

Models 1 and 2 in table 5 report the results for explaining the private sector entry variable, lip. The results show that political support (now lagged) is again significant for this subset of reforms. Likewise, unemployment slows down the speed of restructuring and privatisation. These results are well in line with the intuition that support for reform is more likely to be a decisive factor in planning reforms that directly affect workers' position (whether or not employees are laid off because of restructuring). The fact that unemployment influences directly future restructuring is consistent with the predictions from the Aghion-Blanchard model.

The European Bank for Reconstruction and Development (EBRD) produces a wider set of reform indicators (that have recently been backdated to cover years before 1995). We constructed an average indicator of the following EBRD indices: small scale privatisation, governance and enterprise restructuring, competition policy, banking reform, price liberalisation and trade and foreign exchange liberalisation. This index, ebrd, depicts the cumulative progress in these areas, and its first difference, $d e b r d$, is then used as an alternative reform index in step 2 regressions. These results are 
covered in models 3 and 4 in table 5 . While there are some changes in these results in comparison to the main set of results of table 2 above, main key results are fairly robust: even with the EBRD index, reform support and unemployment retain their signs and remain significant in the parsimonious model.

\section{The role of democracy}

The importance of political constraint may vary according to the degree of political freedom in a country. We examine this by augmenting the first and second step estimations with data from Freedomhouse. Freedomhouse rates all countries according to their political freedom on a scale 1-7, where western type of democracies get grade 1 and complete dictatorship get 7 . We denote this variable by freedom. Based on this index, Freedomhouse classifies countries into 3 groups, free, partially free and not free.

A number of interesting hypotheses arise. Well-established political freedom may reinforce support for market reforms. Thus, freedom is included as a determinant of support for reform in step 1 regressions below. Second, in step 2 regressions, the dependent variable, progress in reforms can depend on the degree of political freedom, and the influence of support for reform may hinge on the level of democracy. It is possible that political constraints are strongest in politically free countries. These hypotheses are tested by including freedom directly into step 2 regressions, and by constructing an interaction variable between freedom and support for reform, i.e., iareform $=$ reform $* f$. This interaction term has positive values only if a country is politically free.

The results are reported in columns 3 and 4 of Table 4 and columns 5 and 6 of Table 5 . For brevity, only results based on GMM estimations are reported here. ${ }^{15}$ Consider first the results of explaining support for reform in Table 4. An increase in the political freedom in the country (a decrease in the value of freedom) increases the support for market-oriented reforms. The role of other determinants remains the same. Increase in political freedom is also positively correlated with ac- 
tual progress in reforms (Table 5, column 6). However, the interaction variables (iareform and lagged iareform) are not significant in explaining progress in reforms. This suggests that while politically free countries are also likely to become more economically free, the strength of political constraints does not vary significantly among politically free and less free countries. One explanation is that most of the countries in the sample have been classified as free or partially free over the whole estimation sample. In addition, even in the absence of complete political freedom, country leaders may have been dependent on the public opinion through some indirect routes, e.g. through a pressure to change the political system.

\section{Conclusion}

This paper investigates relationships between public support for reform, actual progress in reform and economic growth. In order to measure support for a market-oriented reform, we use a novel data set from post-communist countries from 1990 to 1997: the Central and Eastern Eurobarometer surveys.

We use a fixed effect panel and GMM to estimate three equations taking account of endogeneity of support for reform and actual progress in reform for the determinantion of economic grothw. Our results suggest that both ex post and ex ante political constraints influence the extent of reform progress in these countries, supporting predictions of key theoretical work on transition economics. Public support for reform is positively associated with favourable economic conditions affected by earlier reforms and negatively correlated with increases in income inequality and unemployment. In addition, support for reform progress and unemployment affect actual progress in reforms, which in turn are associated with economic growth. In terms of economic significance, our results indicate that a decrease in income equality in Russia to the level of income inequality in Poland would have increased Russia's annual growth rates by $0.85 \%$.

\footnotetext{
${ }^{15}$ Results from LSDV regressions were qualitatively similar and they can be obtained from the authors upon request.
} 
The analysis highlights that while economic reforms are needed to foster growth, they must be designed in such a way that they do not undermine political support for reform. Policies that reduce harmful social impacts of economic growth, such as rising inflation, unemployment or income inequality - which are important in their own right - also create support for market-oriented reforms and should therefore form a crucial element of a successful reform package even from the efficiency point of view.

Due to the paucity of data, our analysis has abstracted from a number of potentially important considerations. One concerns the role of international financial institutions. Many of the countries have followed, at least to some extent, policy advice from institutions such as the IMF, suggesting the chosen reform policies may reflect other considerations other than support among the electorate. Furthermore, institutional differences other than the degree of democratic freedom (which we did consider) may have interesting implications for political economy linkages. In some countries powerful elite groups have arguably been able to influence decision making for rent seeking purposes. In these circumstances, chosen reforms may have again differed from those that would have been chosen in an 'ideal' democracy. 


\section{References}

Aghion, P., and O Blanchard 'On the speed of transition in Central Europe, NBER macroeconomics Annual, pp. 283-320.

Arellano, M and S Bond (1991) 'Some tests of specification for panel data: Monte Carlo evidence and an application to employment equations', Review of Economic Studies 58, 277-297.

Berg, A; E Borensztein; R Sahay and J Zettelmeyer (1999) 'The Evolution of Output in Transition Economies: Explaining the Differences', IMF Working Paper No. 73.

Blanchard, O (1997) 'The Economics of Post-Communist Transition', Oxford: Clarendon Press.

Brunetti, A., Kisunko, G., and Weder, B (1997) 'Institutional obstacles to doing business', World Bank Policy Research Working Paper No. 1759.

Campos, N and F. Coricelli (2001) 'Growth in transition: What we know, what we don't and what we should?', University of Newcastle, mimeo.

Dewatripont, M and G Roland (1992) 'Economic reform and dynamic political constraint', Economic Journal 102, 291-300.

Dewatripont, M and G Roland (1995) 'The design of reform packages under uncertainty', American Economic Review 85, 1207-23.

De Melo, M; C Denizer and A Gelb (1996) 'From Plan to Market: Patterns of Transition', The World Bank, Policy Research Working Paper No. 1564.

Drazen, A (2000) Political economy in macroeconomics. Princeton University Press.

Fernandez, R., and Rodrik, D 1991, 'Resistance to reform: status quo bias in the presence of individual-specific uncertainty', American Economic Review 81, 1146-56. 
Fidrmuc, J (2000) 'Political support for reforms: Economics of voting in transition countries' European Economic Review 44', 1491-1513.

Fidrmuc, J (2001) 'Economic reform, growth and democracy during post-Communist transition' William Davidson Working Paper No. 372.

Fischer, S., Sahay, R., and Vegh, C (1996) 'From transition to market: evidence and growth prospects', IMF Working Paper 98/52.

Fischer, S., Sahay, R., and Vegh, C (1998) 'Stabilization and growth in transition economies: the early experience' Journal of Economic Perspectives 10, 45-66.

Havrylyshyn, O; I Izvorski and R van Rooden (1998) 'Recovery and growth in transition economies 1990-97: a stylized regression analysis’, IMF Working Paper 98/141.

Havrylyshyn, O; and R van Rooden (2000) 'Institutions matter in transition, but so do policies', IMF Working Paper 00/70.

Jackson, J E; J Klich and K Poznanska (2001) 'Economic transition and elections in Poland'. William Davidson Working Paper No. 391.

Krueger, G., and M Ciolko, (1998) 'A note on initial conditions and liberalization during transition', Journal of Comparative Economics 26, 718-734.

Lora, E (1998), 'What makes reforms likely: timing and sequencing of structural reforms in Latin America, Inter-American Development bank, Working Paper 424.

Persson, T and G Tabellini (2000) Political economics - explaining economic policy. MIT University Press.

Pirttilä, J (2001) 'Fiscal policy and structural reforms in transition economies: An empirical analysis', Economics of Transition 9, 29-52 (2001). 
Rodrik, D (1994) 'The rush to free trade in the developing world: why so late? why now? will it last?', Voting for reform: democracy, political liberalization, and economic adjustment. Eds. By Hagard, S., and Webb. S., Washington DC

Rodrik, D. (1996) 'Understanding economic policy reform', Journal of Economic Literature, March 1996, 9-41.

Roland, G (2000) 'Transition and economics: Politics, markets and firms', Cambridge: MIT Press.

Warner, A M (2001) 'Is economic reform popular at polls? Russia 1995', Journal of Comparative Economics 29, 448-465.

Wyplosz, C., (1993), "After the Honeymoon: On the Economics and the Politics of Economic Transformation", European Economic Review 37, 379-386 
Table 1: Determinants of public support for a free market economy

\begin{tabular}{|c|c|c|c|c|}
\hline Model & 1 & 2 & 3 & 4 \\
\hline Dependent var. & reform & reform & reform & reform \\
\hline $\begin{array}{l}\text { Estimation } \\
\text { method }\end{array}$ & $\begin{array}{c}\text { OLS, } \\
\text { fixed effects }\end{array}$ & $\begin{array}{c}\text { OLS, } \\
\text { fixed effects }\end{array}$ & GMM & GMM \\
\hline \multicolumn{5}{|l|}{ Variable } \\
\hline Linfla & $\begin{array}{c}-4.051 * * \\
(-2.05)\end{array}$ & $\begin{array}{c}-2.861 * * \\
(-2.30)\end{array}$ & $\begin{array}{l}-4.278^{*} \\
(-1.73)\end{array}$ & $\begin{array}{l}-4.495 \\
(1.56)\end{array}$ \\
\hline Linfla1 & $\begin{array}{l}2.665 \\
(1.44)\end{array}$ & & $\begin{array}{l}0.763 \\
(0.41)\end{array}$ & \\
\hline Unemp & $\begin{array}{l}-1.570 \\
(-0.11)\end{array}$ & & $\begin{array}{l}-0.851 \\
(-0.50)\end{array}$ & \\
\hline Unemp1 & $\begin{array}{c}-2.201 * * * \\
(-3.13)\end{array}$ & $\begin{array}{c}-2.014 * * * \\
(-4.42)\end{array}$ & $\begin{array}{c}-1.933 * * * \\
(-3.27)\end{array}$ & $\begin{array}{c}-2.442 * * * \\
(-3.43)\end{array}$ \\
\hline Grow & $\begin{array}{l}.119 \\
(0.27)\end{array}$ & & $\begin{array}{l}0.149 \\
(0.26)\end{array}$ & \\
\hline Grow1 & $\begin{array}{c}.238 \\
(0.71)\end{array}$ & & $\begin{array}{c}0.064 \\
(0.209)\end{array}$ & \\
\hline Gini & $\begin{array}{c}-.543 \\
(-0.96) \\
\end{array}$ & $\begin{array}{c}-.650 \\
(-1.28) \\
\end{array}$ & $\begin{array}{l}-0.503 \\
(-0.92)\end{array}$ & $\begin{array}{c}-0.906 * * \\
(-2.15) \\
\end{array}$ \\
\hline Gini1 & $\begin{array}{c}-1.110^{* *} \\
(-2.04)\end{array}$ & $\begin{array}{c}-1.069 * * \\
(-2.20)\end{array}$ & $\begin{array}{l}-0.689 \\
(-0.93)\end{array}$ & $\begin{array}{l}-0.971^{*} \\
(-1.83)\end{array}$ \\
\hline No. of obs. & 67 & 69 & 53 & 55 \\
\hline $\mathrm{R}^{2}$ & 0.29 & 0.28 & & \\
\hline F-test & $\begin{array}{c}\mathrm{F}(8,58)=5.09 \\
{[0.000]}\end{array}$ & $\begin{array}{c}\mathrm{F}(4,64)=10.65 \\
{[0.000]}\end{array}$ & & \\
\hline $\begin{array}{l}\text { Wald (joint sig- } \\
\text { nificance) }\end{array}$ & & & $\begin{array}{c}\mathrm{Chi}^{2}(8)=59.92 \\
{[0.000]}\end{array}$ & $\begin{array}{c}\mathrm{Chi}^{2}(4)=31.61 \\
{[0.000]}\end{array}$ \\
\hline $\begin{array}{l}\text { Sargan test of } \\
\text { overidentifica- } \\
\text { tion }\end{array}$ & & & $\begin{array}{c}\operatorname{Chi}^{2}(112)=61.44 \\
{[1.000]}\end{array}$ & $\begin{array}{c}\operatorname{Chi}^{2}(112)=57.89 \\
{[0.405]}\end{array}$ \\
\hline $\mathrm{AR}(1)$ test & & & $-1.482[0.138]$ & $-1.627[0.104]$ \\
\hline $\mathrm{AR}(2)$ test & & & $0.703[0.482]$ & $0.789[0.430]$ \\
\hline
\end{tabular}

\section{Notes}

This table refers to STEP 1 regressions (dependent variable: support for reform). *, ** and *** denote significance at $10 \%, 5 \%$ and $1 \%$ level, respectively. t-values are based on robust standard errors and reported in brackets. Results in Column (1) and (2) are corrected for heteroskedasticity. pvalues are indicated in squared brackets. 
Table 2: Determinants of progress in reforms

\begin{tabular}{|c|c|c|c|c|c|}
\hline Model & 1 & 2 & 3 & 4 & 5 \\
\hline Dependent var. & li & li & $\mathrm{li}$ & li & li \\
\hline $\begin{array}{l}\text { Estimation } \\
\text { method }\end{array}$ & $\begin{array}{c}2 \mathrm{SLS}, \\
\text { fixed effects }\end{array}$ & $\begin{array}{c}2 \mathrm{SLS}, \\
\text { fixed effects }\end{array}$ & $\begin{array}{c}\text { 2SLS, std errors } \\
\text { bootstrapped }\end{array}$ & GMM & GMM \\
\hline \multicolumn{6}{|l|}{ Variable } \\
\hline Reform & & & & $\begin{array}{c}0.00082 \\
(1.23)\end{array}$ & $\begin{array}{c}0.0030 * * \\
(2.40)\end{array}$ \\
\hline Predicted reform & $\begin{array}{c}0.0037 \\
(1.66) \\
\end{array}$ & $\begin{array}{c}0.0042 * * \\
(2.31) \\
\end{array}$ & $\begin{array}{c}0.0042 * * \\
(2.00)\end{array}$ & & \\
\hline Reform1 & $\begin{array}{c}0.0068 \\
(0.81)\end{array}$ & $\begin{array}{c}0.00087 \\
(1.02)\end{array}$ & $\begin{array}{c}0.00087 \\
(1.01)\end{array}$ & $\begin{array}{c}0.00041 \\
(0.56)\end{array}$ & \\
\hline Linfla & & & & $\begin{array}{l}-0.0086 \\
(-0.660)\end{array}$ & \\
\hline Linfla1 & $\begin{array}{c}0.0065 \\
(0.65) \\
\end{array}$ & $\begin{array}{l}0.0050 \\
(0.52) \\
\end{array}$ & $\begin{array}{c}0.0050 \\
(0.44) \\
\end{array}$ & $\begin{array}{c}0.0091 \\
(0.95)\end{array}$ & \\
\hline Unemp & & & & $\begin{array}{c}0.0038 \\
(0.50) \\
\end{array}$ & \\
\hline Unemp1 & $\begin{array}{c}-0.0298 * * * \\
(3.43)\end{array}$ & $\begin{array}{c}-0.027 * * * \\
(-3.92)\end{array}$ & $\begin{array}{c}-0.027 * * * \\
(-3.53)\end{array}$ & $\begin{array}{c}-0.020 * * \\
(-2.01)\end{array}$ & \\
\hline Grow & & & & $\begin{array}{c}-0.0067 * * * \\
(-3.71)\end{array}$ & $\begin{array}{c}-0.0073 * * * \\
(-3.48)\end{array}$ \\
\hline Grow1 & $\begin{array}{c}0.0019 \\
(1.15) \\
\end{array}$ & $\begin{array}{c}0.0015 \\
(0.96) \\
\end{array}$ & $\begin{array}{c}0.0015 \\
(0.85) \\
\end{array}$ & $\begin{array}{c}0.0023 \\
(1.24) \\
\end{array}$ & \\
\hline Gbal & & & & $\begin{array}{c}0.013^{* * *} \\
(3.61)\end{array}$ & $\begin{array}{c}0.0050 * * * \\
(2.92)\end{array}$ \\
\hline Gbal1 & $\begin{array}{c}0.0016 \\
(0.98) \\
\end{array}$ & & & $\begin{array}{c}-0.0007 \\
(-0.40) \\
\end{array}$ & \\
\hline No. of obs. & 63 & 66 & 66 & 61 & 76 \\
\hline $\mathrm{R}^{2}$ & 0.587 & 0.28 & & & \\
\hline F-test & $\begin{array}{c}\mathrm{F}(6,56)=7.13 \\
{[0.000]}\end{array}$ & $\begin{array}{c}\mathrm{F}(5,60)=16.32 \\
{[0.000]}\end{array}$ & & & \\
\hline $\begin{array}{l}\text { Wald (joint sig- } \\
\text { nificance) }\end{array}$ & & & & $\begin{array}{c}\operatorname{Chi}^{2}(10)=116.2 \\
{[0.000]}\end{array}$ & $\begin{array}{c}\mathrm{Chi}^{2}(3)=14.06 \\
{[0.003]}\end{array}$ \\
\hline $\begin{array}{l}\text { (Sargan) test of } \\
\text { overidentification }\end{array}$ & & $\begin{array}{c}\mathrm{Chi}^{2}(2)=1.617 \\
{[0.445]}\end{array}$ & & $\begin{array}{c}\mathrm{Chi}^{2}(75)=70.93 \\
{[0.612]}\end{array}$ & $\begin{array}{c}\mathrm{Chi}^{2}(51)=56.0 \\
{[0.293]}\end{array}$ \\
\hline $\operatorname{AR}(1)$ test & & & & $-0.850[0.395]$ & $-2.374[0.018]$ \\
\hline $\mathrm{AR}(2)$ test & & & & $-1.090[0.276]$ & $-1.231[0.218]$ \\
\hline
\end{tabular}

Notes: STEP 2 regressions (dependent variable: liberalisation index). *,** and $* * *$ denote significance at $10 \%, 5 \%$ and $1 \%$ level, respectively. t-values are based on robust standard errors and reported in brackets. Results in Column (1) and (2) are corrected for heteroskedasticity. p-values are indicated in squared brackets. 
Table 3: Determinants of economic growth

\begin{tabular}{|c|c|c|}
\hline Model & 1 & 2 \\
\hline Dependent var. & Grow & Grow \\
\hline $\begin{array}{l}\text { Estimation } \\
\text { method }\end{array}$ & GMM & GMM \\
\hline \multicolumn{3}{|l|}{ Variable } \\
\hline Grow1 & $\begin{array}{c}0.399 * * * \\
(7.72)\end{array}$ & $\begin{array}{c}0.374 * * * \\
(3.40)\end{array}$ \\
\hline Predicted li & $\begin{array}{c}-10.09^{*} \\
(-1.75)\end{array}$ & $\begin{array}{l}-0.855 \\
(-1.06)\end{array}$ \\
\hline Lagged cli & $\begin{array}{c}15.575 * * * \\
(3.63)\end{array}$ & $\begin{array}{c}9.044 * * * \\
(2.68)\end{array}$ \\
\hline Linfla & $\begin{array}{c}-2.460 * * \\
(-2.16)\end{array}$ & $\begin{array}{l}-1.236 \\
(-1.34)\end{array}$ \\
\hline Linfla1 & $\begin{array}{l}0.777 \\
(1.42) \\
\end{array}$ & $\begin{array}{l}0.520 \\
(0.46) \\
\end{array}$ \\
\hline Gbal & $\begin{array}{c}.583 * * * \\
(3.10)\end{array}$ & $\begin{array}{l}.380 * * * \\
(2.93)\end{array}$ \\
\hline Gbal1 & $\begin{array}{l}-0.179 \\
(-1.37) \\
\end{array}$ & $\begin{array}{l}-0.921 \\
(-1.03)\end{array}$ \\
\hline Exch & & $\begin{array}{c}2.537^{*} \\
(1.86)\end{array}$ \\
\hline Capf & & $\begin{array}{c}0.240 * * * \\
(4,68)\end{array}$ \\
\hline Capf1 & & $\begin{array}{c}-0.195 * * * \\
(-2.73)\end{array}$ \\
\hline No. of obs. & 49 & 45 \\
\hline $\begin{array}{l}\text { Wald (joint sig- } \\
\text { nificance) }\end{array}$ & $\begin{array}{c}\text { Chi }^{2}(7)=433.66 \\
{[0.000]}\end{array}$ & $\begin{array}{c}\mathrm{Chi}^{2}(10)=3263.39 \\
{[0.000]}\end{array}$ \\
\hline $\mathrm{AR}(1)$ test & $-2.34[0.0195]$ & $-2.20[0.0281]$ \\
\hline $\mathrm{AR}(2)$ test & $0.71[0.480]$ & $-0.04[0.971]$ \\
\hline
\end{tabular}

\section{Notes}

STEP 3 regressions (dependent variable: growth). ${ }^{*}, * *$ and $* * *$ denote significance at $10 \%, 5 \%$ and $1 \%$ level, respectively. $t$-values are based on robust standard errors and reported in brackets. pvalues are indicated in squared brackets. 
Table 4: Determinants of public support for a market economy: robustness check

\begin{tabular}{|c|c|c|c|c|}
\hline Model & 1 & 2 & 3 & 4 \\
\hline Dependent var. & reform & reform & reform & Reform \\
\hline Estimation method & Fixed effects & $\begin{array}{l}\text { Fixed effects- } \\
\text { parsimonious }\end{array}$ & GMM & GMM \\
\hline \multicolumn{5}{|l|}{ Variable } \\
\hline Linfla & $\begin{array}{l}-1.987 \\
(-0.91)\end{array}$ & & $\begin{array}{c}-5.200 * * \\
(-1.94)\end{array}$ & $\begin{array}{l}-3.682^{*} \\
(-1.85)\end{array}$ \\
\hline Linfla1 & $\begin{array}{r}2.864^{*} \\
(1.86) \\
\end{array}$ & & $\begin{array}{l}0.650 \\
(0.43) \\
\end{array}$ & \\
\hline Unemp & $\begin{array}{l}0.406 \\
(0.29) \\
\end{array}$ & & $\begin{array}{l}-0.906 \\
(-0.57) \\
\end{array}$ & \\
\hline Unemp1 & $\begin{array}{l}-0.879 \\
(-1.08)\end{array}$ & $\begin{array}{c}-1.357 * * \\
(-2.31)\end{array}$ & $\begin{array}{c}-1.792 * * * \\
(-2.91)\end{array}$ & $\begin{array}{c}-1.332 * * * \\
(-2.79)\end{array}$ \\
\hline Grow & $\begin{array}{l}-0.171 \\
(-0.46)\end{array}$ & & $\begin{array}{l}-0.105 \\
(-0.18)\end{array}$ & \\
\hline Grow1 & $\begin{array}{l}0.109 \\
(0.33) \\
\end{array}$ & & $\begin{array}{l}-0.020 \\
(-0.07) \\
\end{array}$ & \\
\hline Gini & $\begin{array}{l}-0.958 \\
(-1.60)\end{array}$ & $\begin{array}{c}-1.130 * * \\
(-2.17)\end{array}$ & $\begin{array}{l}-0.315 \\
(-0.59)\end{array}$ & \\
\hline Gini1 & $\begin{array}{c}-0.969^{*} \\
(-1.88)\end{array}$ & $\begin{array}{l}-0.752^{*} \\
(-1.85)\end{array}$ & $\begin{array}{l}-0.986 \\
(-1.36)\end{array}$ & $\begin{array}{l}-0.702 \\
(-1.38)\end{array}$ \\
\hline futloss & $\begin{array}{c}-38.98 * * \\
(-2.64)\end{array}$ & $\begin{array}{c}-27.61 * * * \\
(-3.20)\end{array}$ & & \\
\hline retloss & $\begin{array}{l}14.54 \\
(1.04)\end{array}$ & & & \\
\hline Freedom & & & $\begin{array}{c}-7.263 * * \\
(-2.30) \\
\end{array}$ & $\begin{array}{c}-7.035^{* *} \\
(-2.29) \\
\end{array}$ \\
\hline Freedom 1 & & & $\begin{array}{c}6.057^{*} \\
(1.85)\end{array}$ & \\
\hline No. of obs. & 56 & 60 & 53 & 59 \\
\hline $\mathrm{R}^{2}$ & 0.43 & 0.38 & & \\
\hline F-test & $\begin{array}{c}\mathrm{F}(10.45)=4.69 \\
{[0.0001]}\end{array}$ & $\begin{array}{c}\mathrm{F}(4,53)=11.15 \\
{[0.000]}\end{array}$ & & \\
\hline $\begin{array}{l}\text { Wald (joint signifi- } \\
\text { cance) }\end{array}$ & & & $\begin{array}{c}\operatorname{Chi}^{2}(10)=1113.0 * * * \\
{[0.000]}\end{array}$ & $\begin{array}{c}\operatorname{Chi}^{2}(4)=21.47 * * * \\
{[0.000]}\end{array}$ \\
\hline $\begin{array}{l}\text { Sargan test of } \\
\text { overidentification }\end{array}$ & & & $\begin{array}{c}\operatorname{Chi}^{2}(150)=54.59 \\
{[1.000]}\end{array}$ & $\begin{array}{c}\mathrm{Chi}^{2}(60)=73.23 \\
{[0.117]}\end{array}$ \\
\hline $\mathrm{AR}(1)$ test & & & $-1.345[0.179]$ & $-1.628[0.103]$ \\
\hline $\mathrm{AR}(2)$ test & & & $0.691[0.490]$ & $1.601[0.109]$ \\
\hline
\end{tabular}

\section{Notes}

Alternative STEP 1 regressions. $* * *$ and $* * *$ denote significance at $10 \%, 5 \%$ and $1 \%$ level, respectively. t-values are reported in brackets and p-values squared brackets. Results in Columns (1), (2), (3) and (4) are corrected for heteroskedasticity. 
Table 5: Determinants of progress in reforms: robustness check

\begin{tabular}{|c|c|c|c|c|c|c|}
\hline Model & 1 & 2 & 3 & 4 & 5 & 6 \\
\hline $\begin{array}{l}\text { Dependent } \\
\text { var. }\end{array}$ & lip & lip & debrd & debrd & li & li \\
\hline $\begin{array}{l}\text { Estimation } \\
\text { method }\end{array}$ & Fixed effects & $\begin{array}{c}\text { Fixed effects } \\
- \\
\text { parsimonious }\end{array}$ & Fixed effects & $\begin{array}{c}\text { Fixed effects } \\
- \\
\text { parsimonious }\end{array}$ & GMM & GMM \\
\hline \multicolumn{7}{|l|}{ Variable } \\
\hline $\begin{array}{l}\text { Predicted } \\
\text { reform }\end{array}$ & $\begin{array}{l}0.003 \\
(1.34) \\
\end{array}$ & & $\begin{array}{l}0.012 \\
(1.46) \\
\end{array}$ & & & \\
\hline Reform & & & & & $\begin{array}{c}0.0031 * * * \\
(3.68)\end{array}$ & $\begin{array}{c}0.0021^{*} \\
(1.91)\end{array}$ \\
\hline Reform1 & $\begin{array}{l}0.002 * \\
(1.90)\end{array}$ & $\begin{array}{c}0.002 * * * \\
(2.95) \\
\end{array}$ & $\begin{array}{c}0.005^{* *} \\
(1.99) \\
\end{array}$ & $\begin{array}{c}0.0052^{*} \\
(1.96) \\
\end{array}$ & $\begin{array}{c}0.0016^{*} \\
(1.81) \\
\end{array}$ & \\
\hline Linfla & & & & & $\begin{array}{l}-0.0046 \\
(-0.40) \\
\end{array}$ & \\
\hline Linfla1 & $\begin{array}{l}0.007 \\
(0.58)\end{array}$ & & $\begin{array}{l}0.065 \\
(1.43)\end{array}$ & & $\begin{array}{c}-0.0094 \\
(-0.99)\end{array}$ & \\
\hline Unemp & & & & & $\begin{array}{l}0.0058 \\
(0.75)\end{array}$ & \\
\hline Unemp1 & $\begin{array}{l}-0.006 \\
(-1.22)\end{array}$ & $\begin{array}{c}-0.010 * * * \\
(-3.42)\end{array}$ & $\begin{array}{l}-0.025 \\
(-1.22) \\
\end{array}$ & $\begin{array}{c}-0.456^{* * *} \\
(-3.59)\end{array}$ & $\begin{array}{c}-0.018^{*} \\
(-1.99)\end{array}$ & $\begin{array}{c}-0.026^{* * *} \\
(0.000)\end{array}$ \\
\hline Grow & & & & & $\begin{array}{c}-0.0079 * * * \\
(-4.90)\end{array}$ & \\
\hline Grow1 & $\begin{array}{l}-0.002 \\
(-0.80)\end{array}$ & & $\begin{array}{l}-0.002 \\
(-0.39)\end{array}$ & & $\begin{array}{l}-0.0001 \\
(-0.085)\end{array}$ & \\
\hline Gbal & & & & & $\begin{array}{c}0.013 * * * \\
(4.79)\end{array}$ & $\begin{array}{c}0.0063 * * * \\
(3.40)\end{array}$ \\
\hline Gbal1 & $\begin{array}{l}0.0003 \\
(0.20) \\
\end{array}$ & & $\begin{array}{l}0.008 \\
(1.45) \\
\end{array}$ & & $\begin{array}{c}0.0009 \\
(0.56) \\
\end{array}$ & \\
\hline Freedom & & & & & $\begin{array}{c}-0.067 * * * \\
(-2.98)\end{array}$ & $\begin{array}{c}-0.47 * * \\
(1.99)\end{array}$ \\
\hline Freedom1 & & & & & $\begin{array}{c}0.0036 \\
(0.24) \\
\end{array}$ & \\
\hline Iareform & & & & & $\begin{array}{c}-0.0026^{* *} \\
(-2.43)\end{array}$ & \\
\hline Iareform1 & & & & & $\begin{array}{c}-0.0016 \\
(-1.61)\end{array}$ & \\
\hline No. of obs. & 63 & 81 & 63 & 81 & 61 & 70 \\
\hline $\mathrm{R}^{2}$ & 0.33 & 0.26 & 0.41 & 0.25 & & \\
\hline F-test & $\begin{array}{c}\mathrm{F}(6,56)=7.63 \\
{[0.0000]}\end{array}$ & $\begin{array}{c}\mathrm{F}(2,78)=14.2 \\
3[0.000]\end{array}$ & $\begin{array}{c}\mathrm{F}(6,56)=6.85 \\
{[0.000]}\end{array}$ & $\begin{array}{c}\mathrm{F}(2,78)=12.5 \\
3[0.000]\end{array}$ & & \\
\hline $\begin{array}{l}\text { Wald (joint } \\
\text { significance) }\end{array}$ & & & & & $\begin{array}{c}\operatorname{Chi}^{2}(14)=460 \\
2^{* * *} \\
{[0.000]}\end{array}$ & $\begin{array}{c}\mathrm{Chi}^{2}(4)=29.2 \\
8^{* * *} \\
{[0.000]}\end{array}$ \\
\hline $\begin{array}{l}\text { Sargan test of } \\
\text { overidentifi- } \\
\text { cation }\end{array}$ & & & & & $\begin{array}{c}\mathrm{Chi}^{2}(210)=59 \\
.51 \\
{[1.000]}\end{array}$ & $\begin{array}{c}\mathrm{Chi}^{2}(60)=51 . \\
82 \\
{[0.765]}\end{array}$ \\
\hline $\mathrm{AR}(1)$ test & & & & & $\begin{array}{c}-1.484 \\
{[0.138]} \\
\end{array}$ & $\begin{array}{c}-1.822 \\
{[0.068]}\end{array}$ \\
\hline $\mathrm{AR}(2)$ test & & & & & $\begin{array}{l}-0.832 \\
{[0.405]}\end{array}$ & $0.379[0.704]$ \\
\hline
\end{tabular}

Notes

Alternative STEP 2 regressions. *,** and *** denote significance at $10 \%, 5 \%$ and $1 \%$ level, respectively. t-values are reported in brackets and p-values squared brackets. Results in Columns (1), (2), (3) and (4) are corrected for heteroskedasticity. 